\title{
PREVALENCE OF SOME ANTIMICROBIAL RESISTANCE GENES IN MULTIDRUG RESISTANT SALMONELLA ISOLATED FROM BROILER CHICKENS
}

\author{
WALID H. HASSAN ${ }^{1}$, AHMED H. ABED ${ }^{1}$, ABD EL RADY THABET $^{2}$ \\ and EMAN A.M. EL NADY ${ }^{2}$. \\ ${ }^{1}$ Department of Bacteriology, Mycology and Immunology, Faculty of Veterinary Medicine, Beni-Suef University. \\ ${ }^{2}$ Department of Bacteriology, Animal Health Research Institute, Assiut Branch.
}

Received: 28 June 2017; $\quad$ Accepted: 31 July 2017

\begin{abstract}
Salmonellosis is one of the major bacterial problems in the poultry industry in Egypt and worldwide. Resistance to antimicrobial agents within nontyphoidal Salmonellae is a serious problem. The present study aimed to analyze some $\beta$-lactamase resistance genes in Salmonella isolates from broiler chicken. Five hundred samples were collected from diseased broiler chickens of different ages (3-6 weeks) from different farms in Assiut Governorate during the period from January 2015 to December 2015. Bacteriological examination showed that 26 salmonella isolates were recovered with a prevalence rate of 5.2\% Serotyping of Salmonella isolates showed that S. Enteritidis S. Typhimurium, and S. Kentuky were identified at rates of 50\%, 30.8\% and $19.2 \%$, respectively. Results of antibiogram showed that 18 salmonella isolates (92.3\%) were multidrug resistant. All isolates were screened for the presence of $2 \beta$-lactamase resistance genes $\left(\right.$ bla $_{C T X}$ and bla $\left.a_{C M Y}\right)$ using multiplex PCR. The overall prevalence was 14/26 (53.9\%) for bla $a_{C T X}$ and 9/26 (34.6\%) for bla $a_{C M Y}$.
\end{abstract}

Key words: Multidrug resistance, Broiler chicken, Salmonellae, $\beta$-lactamases.

\section{INTRODUCTION}

Salmonellosis is one of the major bacterial problems in the poultry industry worldwide. salmonella species are responsible for a variety of acute and chronic diseases in both poultry and humans (Okwori et al., 2013).

Although more than 2500 serotypes of salmonella have been identified, in recent years, $S$. enterica serovar Enteritidis ( $S$. Enteritidis) and $S$. enterica serovar Typhimurium ( $S$. Typhimurium) have been recognized as the two major causative agents of salmonellosis in birds, mammals and humans (Darwin and Miller, 1999).

Although antimicrobials are valuable tools to treat clinical disease and to maintain healthy and productive birds, antimicrobial drug use has been implicated as a risk factor in the development and dissemination of drug resistance (Gosh and LaPara, 2007). Food of animal origin and their production environments are reservoirs of both resistant bacteria and resistance genes that could be transferred to

Corresponding author: Dr. EMAN A.M. EL NADY E-mail address: elnadyeman@yahoo.com

Present address: Department of Bacteriology, Animal Health Research Institute, Assiut Branch. humans either by direct contact or indirectly via the food production chain (WHO, 2011). Therefore, the appropriate antibiotic should better be selected on the basis of its sensitivity which could be detected by laboratory examination. The recovery of antimicrobial-resistant salmonella in foods of animal origin has raised concerns that the treatment of human salmonellosis may be compromised because antimicrobial-resistant strains appear to be more often associated with severe disease than are susceptible isolates. Of significant concern is the isolation of salmonella exhibiting decreased susceptibility to fluoroquinolones (e.g., ciprofloxacin) and extendedspectrum cephalosporins (e.g., ceftiofur and ceftriaxone), because these two antimicrobial classes are important in treating salmonella infections in adults and children, respectively (Gupta et al., 2003).

Resistance to antimicrobial agents within nontyphoidal salmonella serotypes is considered a serious problem worldwide. Surveillance data demonstrates an obvious increase in overall antimicrobial resistance among salmonellae from 20$30 \%$ in the early 1990 s to as high as $70 \%$ in some countries in the 2000s (Su et al., 2004). More than 340 beta-lactamases have been described in salmonella and the prevalence of genes encoding for them varies region by region (Hasman et al., 2005). 
The purpose of this study was genetic analysis of some $\beta$-lactamase resistance genes in salmonellae isolates from broiler chicken.

\section{MATERIALS AND METHODS}

\section{1 - Samples}

Five hundred samples were collected from diseased broiler chickens (suspected to harbor salmonella) of different ages (3-6 weeks). Sampling were carried out from different farms in Assiut Governorate during the period from January 2015 to December 2015. These chickens were subjected to clinical and postmortem examinations. Samples were collected aseptically from the lesions in the internal organs including liver, heart, lung, air sacs, and kidney.

\section{2 - Isolation and identification of Salmonella species}

Samples were cultured into selenite-F broth and incubated at $37^{\circ} \mathrm{C}$ for $18-24 \mathrm{hrs}$. Then, a loopful of this culture was streaked out onto MacConkey's agar then the non-lactose fermenter (pale) colonies were streaked onto xylose lysine deoxycholate (XLD) and Salmonella-Shigella (SS) agar media and incubated at $37^{\circ} \mathrm{C}$ for $18-24$ hours. All isolates were identified as salmonella species based on their colony morphology and biochemical tests according to schemes described by Collee et al. (1996) and Quinn et al. (2002). The salmonella isolates were also confirmed biochemically by using the API 20E system (BioMérieux, Marcy-l'Étoile, France).

\section{3 - Serotyping of Salmonella species}

Salmonella isolates were serotyped by slide agglutination test carried out according to KauffmanWhite scheme (Kauffman, 1974) for the determination of Somatic (O) and flagellar $(\mathrm{H})$ antigens using salmonella antiserum (DENKA SEIKEN Co., Japan).

\section{4 - Antimicrobial susceptibility testing}

All Salmonella isolates were tested for their antimicrobial susceptibility to 14 different antimicrobial discs including erythromycin $(15 \mu \mathrm{g})$, nalidixic acid $(30 \mu \mathrm{g})$, penicillin (10 IU), amoxicillin $(30 \mu \mathrm{g})$, oxytetracycline $(30 \mu \mathrm{g})$, sulphamethoxazoletrimethoprime $(25 \mu \mathrm{g})$, ampicillin $(10 \mu \mathrm{g})$,

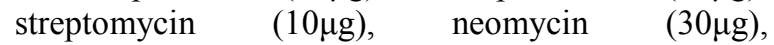

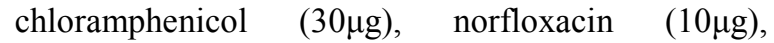
ciprofloxacin $(5 \mu \mathrm{g})$, kanamycin $(30 \mu \mathrm{g})$ and gentamicin $(10 \mu \mathrm{g})$ (Oxoid Limited, Basing Stoke, UK). Antimicrobial susceptibility testing was performed using disc diffusion method on Muller Hinton agar according to CLSI (2015). The antimicrobial susceptibility was based on the induced inhibition zones according to the guidelines of the CLSI (2015). Resistance to two/or more antimicrobials of different classes was taken as multidrug resistant (MDR) (Chandran et al., 2008).

\section{5 - Multiplex-PCR for detection of $\beta$-lactamases resistance genes}

\section{1- DNA extraction:}

DNA was extracted by using bacterial DNA e xtraction kits (Qiagen, Germany, GmbH) according to the manufacturer instructions.

\section{2- Screening of $\beta$-lactamases resistance genes by multiplex-PCR:}

The multiplex-PCR assay was applied on 26 salmonella isolates for detection of $2 \beta$-lactamase resistance genes $b a_{C T X}$ (responsible for cefotaxime resistance) and $b a_{C M Y}$ (responsible for cephalosporin resistance) according to (Ahmed et al., 2009). Targeted genes and their primer sequences are listed in (Table 1).

Table 1: Primer sequences and amplified products for the $\beta$-lactamase resistance genes blaCTX and blaCMY.

\begin{tabular}{|c|c|c|c|c|}
\hline Gene & & Primer Sequence 5'-3' & Amplified product & Reference \\
\hline \multirow[t]{2}{*}{$B l a_{C T X}$} & $F$ & CGCTTTGCGATGTGCAG & & \multirow{4}{*}{ Ahmed et al. (2009) } \\
\hline & $\bar{R}$ & ACCGCGATATGCTTGGT & $550 \mathrm{bp}$ & \\
\hline \multirow[t]{2}{*}{$B l a_{C M Y}$} & $F$ & GACGCCTCTTTCTCCACA & & \\
\hline & $R$ & TGGAACGAAGGCTACGTA & $1007 \mathrm{bp}$ & \\
\hline
\end{tabular}

\section{RESULTS}

1 - Bacteriological isolation of salmonella species. Out of 500 broiler chicken samples, 26 salmonella isolates were recovered with a prevalence rate of $5.2 \%$.

\section{2 - Serotyping of salmonella isolates.}

The 26 salmonella isolates were serotyped as $13 \mathrm{~S}$. Enteritidis (50\%), 8 S. Typhimurium (30.8\%) and 5 S. Kentuky (19.2\%).

\section{3 - Antimicrobial susceptibility testing.}

Results of in-vitro sensitivity tests showed that salmonella isolates were completely resistant to erythromycin and penicillin while they were highly resistant to amoxicillin and streptomycin $(92.3 \%$ for both), nalidixic acid (80.8\%), sulphamethoxazoletrimethoprime (76.9\%), ampicillin (69.2\%) and oxytetracycline $(65.4 \%)$. On contrary, salmonella strains were highly sensitive to kanamycin (96.2\%) then gentamycin $(73.1 \%)$ (Table 2). MDR salmonella isolates were 24 isolates $(92.3 \%)$. 
Table 2: Distribution of Antimicrobial susceptibility for 26 salmonella isolates.

\begin{tabular}{|c|c|c|c|c|c|c|}
\hline \multirow{2}{*}{ Antimicrobial agent } & \multicolumn{2}{|c|}{ Sensitive } & \multicolumn{2}{|c|}{ Intermediate } & \multicolumn{2}{|c|}{ Resistant } \\
\hline & NO. & $\%$ & NO. & $\%$ & NO. & $\%$ \\
\hline Erythromycin (E) & - & - & - & - & 26 & 100 \\
\hline Penicillin(P) & - & - & - & - & 26 & 100 \\
\hline Amoxicillin (AMX) & - & - & 2 & 7.7 & 24 & 92.3 \\
\hline Streptomycin $(\mathbf{S})$ & 2 & 7.7 & - & - & 24 & 92.3 \\
\hline Nalidixic acid (NA) & 2 & 7.7 & 3 & 11.5 & 21 & 80.8 \\
\hline Sulphamethoxazol-trimethoprime (SXT) & 4 & 15.4 & 2 & 7.7 & 20 & 76.9 \\
\hline Ampicillin (AMP) & 5 & 19.2 & 3 & 11.5 & 18 & 69.2 \\
\hline Oxytetracycline $(\mathrm{T})$ & 5 & 19.2 & 4 & 15.4 & 17 & 65.4 \\
\hline Chloramphenicol (C) & 7 & 26.9 & 6 & 23.1 & 13 & 50.0 \\
\hline Norfloxacin (NOR) & 11 & 42.3 & 5 & 19.2 & 10 & 38.5 \\
\hline Neomycin $(\mathbf{N})$ & 13 & $\mathbf{5 0 . 0}$ & 7 & 26.9 & 6 & 23.1 \\
\hline Ciprofloxacin (CIP) & 14 & 53.8 & 8 & 30.8 & 4 & 15.4 \\
\hline Gentamycin (G) & 19 & 73.1 & 5 & 19.2 & 2 & 7.7 \\
\hline Kanamycin (K) & 25 & 96.2 & - & - & 1 & 3.8 \\
\hline
\end{tabular}

4 - Multiplex-PCR for detection of $\beta$-lactamases resistance genes (bla $a_{C T X}$ and bla $\left._{C M Y}\right)$.

Multiplex-PCR assay was done for 26 salmonella strains for detection of $2 \beta$-lactamase resistance genes $b l a_{C T X}$ and $b l a_{C M Y}$. The results revealed that bla $a_{C T X}$ gene was found in 14/26 isolates (53.9\%) arranged as follow; 8 S. Enteritidis (30.8\%), 4 S. Typhimurium $(15.4 \%)$ and 2 S. Kentucky (7.7\%). Meanwhile, $b l a_{C M Y}$ gene was found in 9/26 isolates (34.6\%) arranged as follow; $4 \mathrm{~S}$. Enteritidis (15.4\%), $3 \mathrm{~S}$. Typhimurium (11.5\%) and 2 S. Kentucky (7.7\%) (Tables $3 \& 4$ and Fig. 1\& 2)

Table 3: Multiplex-PCR results for $\beta$-lactamase resistance genes in salmonella isolates.

\begin{tabular}{|c|c|c|c|c|c|c|c|}
\hline NO & Serotype & bla $_{\text {CTX }}$ & bla $_{C M Y}$ & NO & Serotype & bla $_{C T X}$ & $b^{b l a} a_{C M Y}$ \\
\hline 1 & S. Enteritidis & + & - & 14 & S. Typhimurium & + & - \\
\hline 2 & S. Enteritidis & + & + & 15 & S. Typhimurium & - & + \\
\hline 3 & S. Enteritidis & - & - & 16 & S. Typhimurium & - & - \\
\hline 4 & S. Enteritidis & - & - & 17 & S. Typhimurium & + & - \\
\hline 5 & S. Enteritidis & + & - & 18 & S. Typhimurium & + & + \\
\hline 6 & S. Enteritidis & - & - & 19 & S. Typhimurium & - & + \\
\hline 7 & S. Enteritidis & + & - & 20 & S. Typhimurium & + & - \\
\hline 8 & S. Enteritidis & + & + & 21 & S. Typhimurium & - & - \\
\hline 9 & S. Enteritidis & + & + & 22 & S. Kentucky & - & + \\
\hline 10 & S. Enteritidis & + & - & 23 & S. Kentucky & - & - \\
\hline 11 & S. Enteritidis & - & - & 24 & S. Kentucky & + & - \\
\hline 12 & S. Enteritidis & - & + & 25 & S. Kentucky & - & - \\
\hline 13 & S. Enteritidis & + & - & 26 & S. Kentucky & + & + \\
\hline
\end{tabular}


Table 4: Resistance phenotype and prevalence of $\beta$-lactamase resistance genes in salmonella isolated from diseased broilers.

\begin{tabular}{|c|c|c|c|}
\hline NO & Serotype & Resistance phenotypes & Resistance gene \\
\hline 1 & S. Enteritidis & E, P,AMX, S, NA, SXT, AMP, T, C, NOR, N, CIP, G & bla $_{C T X}$ \\
\hline 2 & S. Enteritidis & E, P,AMX, S, NA, SXT, AMP, T, C, NOR, N & bla $_{C T X}$, bla $_{C M Y}$ \\
\hline 5 & S. Enteritidis & E, P, AMX, S, NA, SXT, AMP, T, C & bla $_{C T X}$ \\
\hline 7 & S. Enteritidis & E, P,AMX, S, NA, SXT, AMP, T & bla $_{C T X}$ \\
\hline 8 & S. Enteritidis & E, P,AMX, S, NA, SXT, AMP, T & bla $_{C T X}$, bla $_{C M Y}$ \\
\hline 9 & S. Enteritidis & E, P,AMX, S, NA, SXT & bla $_{C T X}$, bla $_{C M Y}$ \\
\hline 10 & S. Enteritidis & E, P,AMX, S, NA, SXT & bla $_{C T X}$ \\
\hline 12 & S. Enteritidis & E, P,AMX, S & bla $_{C M Y}$ \\
\hline 13 & S. Enteritidis & $\mathbf{E}, \mathbf{P}$ & bla $_{\text {CTX }}$ \\
\hline 14 & S. Typhimurium & E, P,AMX, S, NA, SXT, AMP, T, C, NOR, N, CIP, G, K & bla $_{C T X}$ \\
\hline 15 & S. Typhimurium & E, P,AMX, S, NA, SXT, AMP, T, C, NOR, N, CIP & bla $_{C M Y}$ \\
\hline 17 & S. Typhimurium & E, P,AMX, S, NA, SXT, AMP, T, C, NOR & bla $_{C T X}$ \\
\hline 18 & S. Typhimurium & E, P,AMX, S, NA, SXT, AMP, T, C, NOR & bla $_{C T X}, b_{\text {la }} a_{C M Y}$ \\
\hline 19 & S. Typhimurium & E, P,AMX, S, NA, SXT, AMP, T, C & bla $_{C M Y}$ \\
\hline 20 & S. Typhimurium & E, P,AMX, S, NA, SXT, AMP, T, C & bla $_{C T X}$ \\
\hline 22 & S. Kentucky & E, P,AMX, S, NA, SXT, AMP, T, C, NOR, N, CIP & bla $_{C M Y}$ \\
\hline 24 & S. Kentucky & E, P, AMX, S, NA, SXT, AMP & bla $_{C T X}$ \\
\hline 26 & S. Kentucky & $\mathbf{E}, \mathbf{P}$ & bla $_{C T X}$, bla $_{C M Y}$ \\
\hline
\end{tabular}
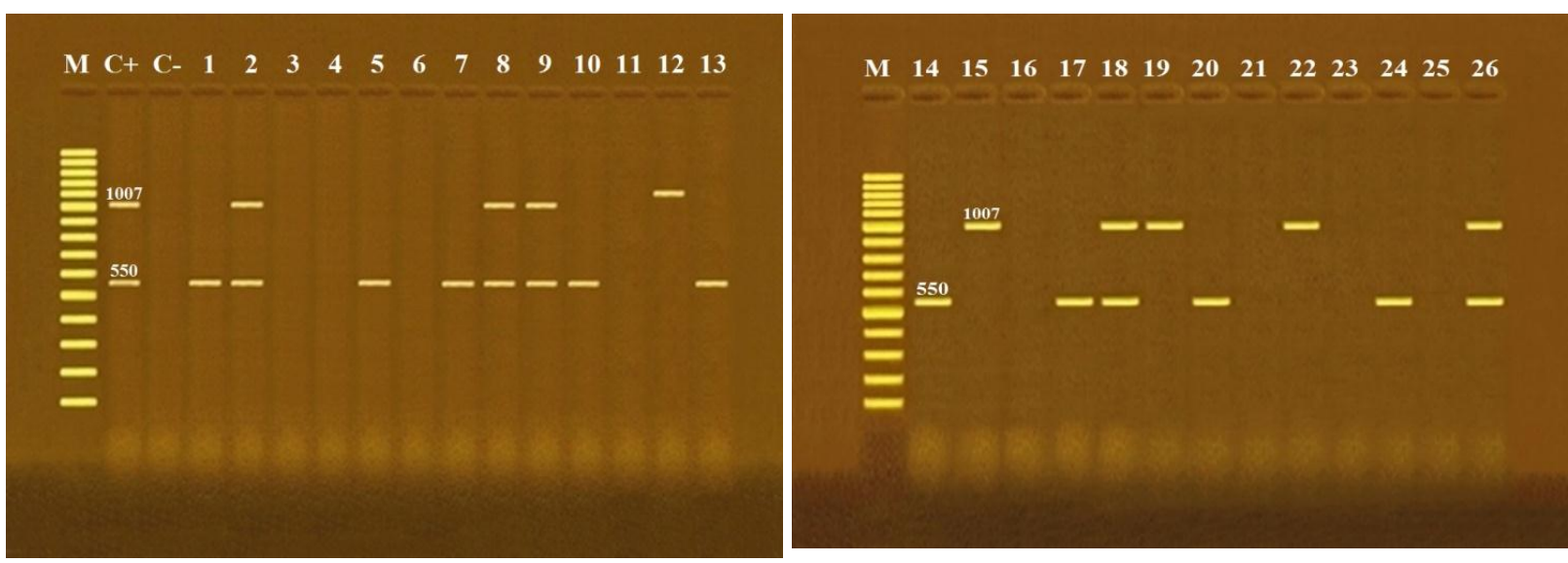

Fig. (1\& 2): PCR amplification of the 550bp and $1007 \mathrm{bp}$ fragments of bla $a_{C T X}$ and bla $_{C M Y}$ genes, respectively, from 26 Salmonella isolates (1-26) showing positive amplicons migrates with the molecular 100 bp ladder marker (M)., C+ (control positive), C- (control negative). S.Enteritidis (1-13), S.Typhimurium (14-21), S.Kentucky (22-26)

\section{DISCUSSION}

Salmonellosis causes great mortalities and various morbidity changes as well as economic losses in poultry industry and a serious public health problem throughout the world (Pedersen et al., 2002). Identification and genotyping of salmonella isolates are essential for epidemiological surveillance and investigations of outbreak.

In the current work, 26 salmonella species were recovered from the 500 samples of internal organs (liver, heart, lung, airsacs, and kidney) of broiler chickens with prevalence rate of $5.2 \%$. This result was similar to that obtained by reported by Abd ElGalil et al. (1995); 6\%, and nearly similar to those of Abd El Fattah (2014); 8.72\%, and Radwan et al. (2016); 12\%, while it was much lower than that reported by Sharada et al. (1999); 30.5\%.

Serotyping of 26 salmonella isolates showed that S.Enteritidis, S.Typhimurium and S.Kentuky were identified at rates of $50 \%, 30.8 \%$ and $19.2 \%$, respectively. The obtained results run parallel to that obtained by Hegazy (2002) who detected S.Enteritidis and S. Kentucky at rates of $62.16 \%$, and $5.41 \%$ respectively. 
Antimicrobial therapy is one of the primary control for reducing both the incidence and mortality associated with avian diseases therefore reducing their enormous losses in the poultry industry (Radwan et al., 2016). Increasing antimicrobial resistance is an important public health concern, and the emergence and spread of antimicrobial resistance is a complex problem driven by numerous interconnected factors. In-vitro antimicrobial susceptibility testing of veterinary pathogens can provide valuable guidance to the veterinarian in the choice of appropriate chemotherapy (Radwan et al., 2016). Moreover, it is very useful to detect the multidrug resistant isolates.

In the present study, the recovered salmonella isolates $(n=26)$ were subjected to in-vitro antimicrobial susceptibility tests against 14 different antimicrobial drugs to detect MDR isolates for further analyses of the isolates. Results illustrated in table (2) revealed that Salmonella isolates showed complete resistance against erythromycin and penicillin while they were highly resistant to amoxicillin and streptomycin (92.3\% for both), nalidixic acid (80.8\%), sulphamethoxazole-trimethoprime (76.9\%), ampicillin (69.2\%) and oxytetracycline (65.4\%). On the other hand, they were highly sensitive to kanamycin (96.2\%) then gentamycin $(73.1 \%)$. MDR salmonella isolates were 24 isolates with prevalence rate of $92.3 \%$. Comparable results have been reported worldwide; in Egypt (Ahmed et al., 2009), in USA (Frye and Fedorka-Cray, 2007), and in Italy (Mammina et al., 2002), and in Portugal (Antunes et al., 2006).

Beta-lactams belong to a family of antibiotics, the members of which have a $\beta$-lactam ring. Penicillins, cephalosporins, clavams (or oxapenams), cephamycins and carbapenems are members of this family. In Gram-negative bacteria, resistance to $\beta$ lactam antibiotics is primarily mediated by $\beta$ lactamases, which hydrolyze the $\beta$-lactam ring and thus inactivate the antibiotic. Many different $\beta$ lactamases have been described, but TEM-, $S H V$-, $O X A-, C M Y$ - and $C T X-M-\beta$-lactamases are the most predominant in Gram-negative bacteria. bla $a_{C T X-M}$ arise resistance to penicillins, extended-spectrum cephalosporins, and monobactams, and the enzymes are inhibited by clavulanate, sulbactam, and tazobactam. Typically, the CTX-M-ases hydrolyze cefotaxime more efficiently than ceftazidime, which is reflected in substantially higher MICs to cefotaxime than to ceftazidime (Livermore and Woodford, 2006).

In the current study $2 \beta$-lactamase resistance genes (bla $a_{C T X}$ and $b l a_{C M Y}$ ) were evaluated in all salmonella isolates $(n=26)$ using multiplex-PCR assay. The results illustrated in tables ( $3 \& 4)$ and Fig. ( $1 \& 2$ ) revealed that bla $_{\text {CTX }}$ gene was found in 14/26 isolates (53.9\%) arranged as follow; 8 S. Enteritidis (30.8\%),
4 S. Typhimurium (15.4\%) and 2 S. Kentucky (7.7\%). The resistance gene $b l a_{C T X}$ has previously been identified and reported increasingly in Gram-negative rods (Bradford, 2001; Bonnet, 2004; Eckert et al., 2004; Lartigue et al., 2005; Naas et al., 2005 and Pitout et al., 2005) and was characterized and isolated in Germany and Italy (Barthelemy et al., 1992 and Bauernfeind et al., 1996). On the other hand, bla $a_{C M Y}$ gene was found in 9/26 isolates $(34.6 \%$ ) arranged as follow; 4 S. Enteritidis (15.4\%), 3 S. Typhimurium $(11.5 \%)$ and $2 S$. Kentucky (7.7\%). The gene bla ${ }_{C M Y}$ has previously been identified in $S$. Typhimurium and other serovars isolated from animals in Canada (Allen and Poppe, 2002), Egypt (Ahmed et al., 2009) and USA (Doublet et al., 2004; Frye and Fedorka-Cray, 2007 and Zhao et al., 2007).

\section{CONCLUSION}

The presence of multidrug resistance pathogens occurred due to the misuse of the antibiotics and it is considered a great problem. In this study, multidrugresistant strains of $S$. Enteritidis, S. Typhimurium and S. Kentucky from diseased broilers were recovered and identified. Furthermore, 2 important antimicrobial resistance genes (bla $a_{C T X}$ and $b l a_{C M Y}$ ) were characterized using multiplex-PCR. These resistance genes confer resistance to many antimicrobial agents regularly used in poultry farming and hospitals.

\section{REFERENCES}

Abd El Fattah, A.A. (2014): Bacteriological studies on the bacteria associated with dead -in shell and early mortalities in chicks. M. V. Sc. Thesis (Microbiology), Fact. Vet. Med., BeniSuef Univ., Egypt.

Abd El-Galil, Y.; El-Kenawy, A.I.; El-Gmiey, S.R. and Abd El-Latif, M.M. (1995): Bacterial causes of lowering hatchabilityand early embryonic chicken deaths in balady hatcheries in Dakahlia Governorate. Assiut Vet. Med. J., 33 (6).

Ahmed, A.M.; Younis, E.E.A.; Ishida, Y. and Shimamoto T. (2009): Genetic basis of multidrug resistance in Salmonellaenterica serovars Enteritidis and Typhimurium isolated from diarrheic calves in Egypt. Acta. Trop., 111: 144-149.

Allen, K.J. and Poppe, C. (2002): Occurrence and characterization of resistance to extendedspectrum cephalosporins mediated by $\beta$ lactamase $C M Y-2$ in Salmonella isolated from food-producing animals in Canada. Can. J. Vet. Res., 66: 137-144.

Antunes, P.; Machado, J. and Peixe, L. (2006): Characterization of antimicrobial resistance and class 1 and 2 integrons in Salmonellaenterica isolates from different 
sources in Portugal. J. Antimicrob. Chemother., 58: 297-304.

Barthelemy, M.; Peduzzi, J.; Bernard, H.; Tancrede, C. and Labia, R. (1992): Close amino acid sequence relationship between the new plasmid-mediated extended spectrum betalactamase MEN-1 and chromosomally encoded enzymes of Klebsiellaoxytoca. Biochim. Biophys. Acta., 1122:15-22.

Bauernfeind, A.; Stemplinger, I.; Jungwirth, R.; Ernst, S. and Casellas, J.M. (1996): Sequences of beta-lactamase genes encoding $C T X-M-1$ $(M E N-1)$ and $C T X M-2$ and relationship of their amino acid sequences with those of other betalactamases Antimicrob. Agents Chemother., 40:509-513.

Bonnet, R. (2004): Growing group of extended spectrum $\beta$-lactamases: the CTX-M enzymes. Antimicrob. Agents Chemother., 48:1-14.

Bradford, P.A. (2001): Extended-spectrum $\beta$ lactamases in the $21^{\text {st }}$ century: characterization, epidemiology, and detection of this important resistance threat. Clin.Microbiol. Rev., 14: 933-951.

Chandran, A.; Hatha, A.; Varghese, S. and Mony Sheeja, K. (2008): Prevalence of multiple drug resistant $E$. coli serotypes in a tropical estuary, India. Microbes Environ. 23 (2):153-158.

CLSI, Clinical and Laboratory Standards Institute (2015): Performance Standards for Antimicrobial Susceptibility Testing; TwentyFifth Informational Supplement (M100-S25). Vol 35 (3) P. 64, Wayne, PA, USA.

Collee, J.G.; Fraser, A.G.; Marmion, B.P. and Simmons, A. (1996): Practical Medical Microbiology. $14^{\text {th }}$ Ed.

Darwin, K.H. and Miller, V.L. (1999): Molecular basis of the interaction of Salmonella with the intestinal mucous. Clin.Microbiol. Rev., 12: 405-428.

Doublet, B.; Caratolli, A.; Whichard, J.M.; White, D.G.; Baucheron, S.; Chaslus-Dancla, E. and Cloeckaert, A. (2004): Plasmid-mediated florfenicol and ceftriaxone resistance encoded by the floR and $b l a_{C M Y-2}$ genes in Salmonellaenterica serovars Typhimurium and Newport isolated in the United States. FEMS Microbiol. Lett., 15: 301-305.

Eckert, C.; Gautier, V.; Saladin-Allard, M.; Hidri, N.; Verdet, C.; Ould-Hocine, Z.; Barnaud, G.; Delisle, F.; Rossier, A.; Lambert, T.; Philippon, A. and Arlet, G. (2004): Dissemination of $C T X$ - $M$-type beta-lactamases among clinical isolates of Enterobacteriaceae in Paris, France. Antimicrob. Agents Chemother., 48:1249-1255.

Frye, J.G. and Fedorka-Cray, P.J. (2007): Prevalence, distribution and characterization of ceftiofur resistance in Salmonellaenterica isolated from animals in the USA from 1999 to 2003. Int. J. Antimicrob Agents, 30: 134-142.

Gosh, S. and LaPara, T.M. (2007): The effects of sub-therapeutic antibiotic use in farm animals on the proliferation and persistence of antibiotic resistance among soil bacteria. ISME J, 1: 191-203.

Gupta, A.; Fontana, J.; Crowe, C.; Bolstorff, B.; Stout, A.; Van Duyne, S.; Hoekstra, M.P.; Whichard, J.M.; Barrett, T.J. and Angulo, F.J. (2003): Emergence of multidrug-resistant Salmonella enterica serotype Newport infections resistant to expanded-spectrum cephalosporinsin the United States. J. Infect. Dis. 188:1707-1716.

Hasman, H.; Mevius, D.; Veldman, K.; Olesen, I. and Aarestrup, F.M. (2005): Beta-Lactamases among extended-spectrum beta-lactamase (ESBL)-resistant Salmonella from poultry, poultry products and human patients in The Netherlands. J. Antimicrob. Chemother., 56: 115-121.

Hegazy, A.E. (2002): Epidemiological studies on Salmonellosis in chickens with special reference to Salmonella Enteritidis. Ph. D. Thesis., Fac. Vet. Med., Alex. Univ., Egypt.

Kauffman, G. (1974): Kauffmann white scheme. J. Acta. Path. Microbiol. Sci., 61:385.

Lartigue, M.F.; Poirel, L.; Decousser, J.W. and Nordmann, P. (2005): Multidrug resistant Shigellasonnei and Salmonella enterica serotype Typhimurium isolates producing $C T X-M$ beta-lactamases as causes of community-acquired infection in France. Clin. Infect. Dis., 40:1069-1070.

Livermore, D.M. and Woodford, N. (2006): The $\beta$ lactamase threat in Enterobacteriaceae, Pseudomonas and Acinetobacter. Trends Microbiol., 14: 413-420.

Mammina, C.; Cannova, L.; Massa, S.; Goffredo, E. and Nastasi, A. (2002): Drug resistances in Salmonella isolates from animal foods, Italy1998-2000. Epidemiol. Infect., 129: 155161.

Naas, T.; Lezzar, A.; Bentchouala, C.; Smati, F.; Scheftel, J.M.; Monteil, H. and Nordmann, P. (2005): Multidrug-resistant Salmonella enterica serotype Senftenberg isolates producing $C T X-M$ beta-lactamases from Constantine, Algeria. J. Antimicrob. Chemother. 56:439-440.

Okwori, A.E.J.; Ogbe, R.J.; Chollom, S.C.; Agada, G.O.A.; Ujah, A.; Okwori, E.; Adeyanju, O.N. and Echeonwu, G.O.N. (2013): Isolation of Salmonella Gallinarum from poultry droppings in Jos metropolis, Plateau State, Nigeria.

Pedersen, K.; Hansen, H.C.; Jorgensen, J.C. and Borck, B. (2002): Serovars of Salmonella isolated from Danish turkeys between 1995 
and 2000 and their antimicrobial resistance. Vet. Rec., 150(15): 471-474.

Pitout, J.D.; Nordmann, P.; Laupland, K.B. and Poirel, L. (2005): Emergence of Enterobacteriaceae producing extendedspectrum betalactamases (ESBLs) in the community. J. Antimicrob. Chemother., 56:5259.

Quinn, P.J.; Markey, B.K.; Carter, M.E.; Donnelly, W.J.C.; Leonard, F.C. and Maguire, D. (2002): Veterinary Microbiology and Microbial Disease. Published by Blackwell. PP. 113-116.

Radwan, I.A.; Abed, A.H.; Abd Al-Wanis, S.A.; Abd El-Aziz, G.G. and El-Shemy. A. (2016): Antibacterial effect of cinnamon and oreganium oils on multidrug resistant Escherichiacoli and Salmonellae isolated from broiler chickens. J. Egy. Vet. Med, Ass., 76(2): 169-186.
Sharada, R.; Krishneppa, G.; Raghavan, R.; Gowda, R.N.S. and Upendra, H.A. (1999): Isolation and serotyping of Escherichia coli from different pathological conditions inpoultry. Ind. J. Poult. Sci., 34 (3): 336-369.

Su, L.H.; Chiu, C.H.; Chu, C. and Ou, J.T. (2004): Antimicrobial resistance in nontyphoid Salmonella serotypes: a global challenge. Clin. Infect. Dis., 39: 546-551.

WHO, World Health Organization (2011): Tackling antibiotic resistance from a food safety perspective in Europe. Available: http://www.euro.who.int/data/assets/pdf_file/0 005/136454/ e94889.pdf.

Zhao, S.; McDermott, P.F.; White, D.G.; Qaiyumi, S.; Friedman, S.L.; Abbott, J.W.; Glenn, A.; Ayers, S.L.; Post, K.W.; Fales, W.H.; Wilson, R.B.; Reggiardo, C. and Walker, R.D. (2007): Characterization of multidrug resistant Salmonella recovered from diseased animals. Vet. Microbiol., 123: 122-132.

\section{دراسة عن انتثار بعض الجينات المسبية للمقاومة ضد مضادات الميكرويات فى عترات السالمونيلا متعددة المقاومة للادوية المعزولة من الاجاج اللاحم (بدارى التسمين)}

وليب حسن ، أحد حسين ، عبد الراضى ثابت ، إيمان أبويكر محدد النادى

Email: elnadyeman@yahoo.com Assiut Universityweb-site: www.aun.edu.eg

السالمونيلا تعتبر و احدة من كبرى المشاكل البكتيرية فى صناعة الدو اجن فى مصر وجميع انحاء العالم. وتعتبر المقاومة ضد مضادات

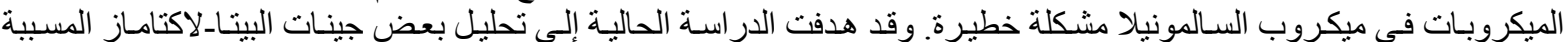

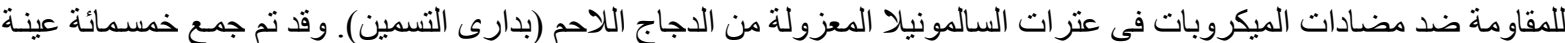

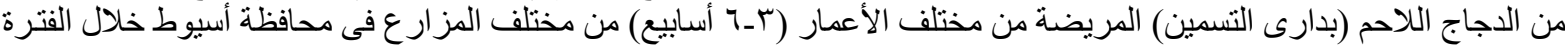

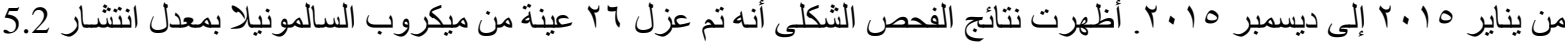

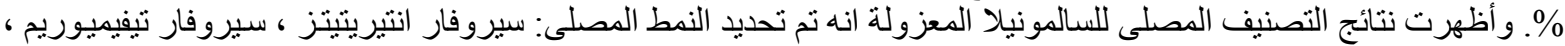

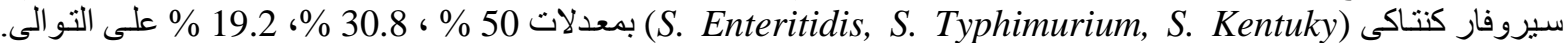

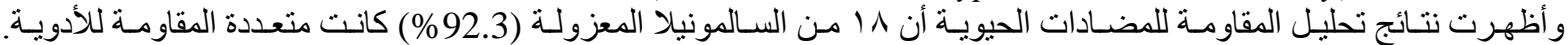

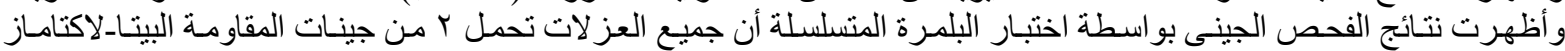

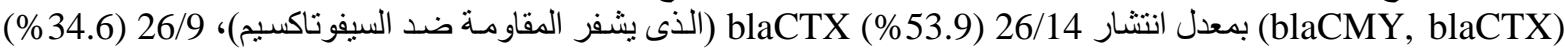

blaCMY (الذى يشفر المقاومة ضد الكيفالوسبورن). 